International

Medical Society

http://imedicalsociety.org

\title{
Medical Conditions and Risks Associated with Pressure Ulcers
}

Maria do Livramento Silva', Simone Helena dos Santos Oliveira², Edienne Rosângela Sarmento Diniz ${ }^{3}$, Marta Miriam Lopes Costa ${ }^{4}$, Maria do Carmo Andrade Duarte de Farias ${ }^{5}$, Maria Julia Guimarães Oliveira Soares ${ }^{6}$

\section{Abstract}

Introduction: Pressure ulcers are common among bedridden patients with little or no mobility.

Objective: To determine the prevalence of pressure ulcers and analyse their association with clinical conditions and risk factors in intensive care unit (ICU) patients.

Method: This is a prospective and quantitative study conducted with 45 patients in the public hospital ICU in João Pessoa, Paraíba, Brazil. Data were collected through hospital records, physical examination, and the Braden Scale. Data were analysed using descriptive statistics and association tests.

Results: The study presented a pressure ulcer prevalence of 37.8\%, verifying significant associations between the occurrence and the consciousness level, hydration, and skin texture. The association with the subscale friction and shear was also significant.

Conclusion: Nursing staff must be involved in the prevention of pressure ulcers in primary care.
1 Master in nursing. Nurse at the Hospital of the Military Police General Edson Ramalho. João Pessoa, Paraíba, Brazil.

2 PhD in Nursing. Teacher at the Federal University of Paraíba. João Pessoa, Paraíba, Brazil.

3 Master in nursing. Nurse at the Children's Hospital Luis Marques.

$4 \mathrm{PhD}$ in Sociology. Teacher at the Federal University of Paraíba. João Pessoa, Paraíba, Brazil.

5 Academic Unit of Life Sciences, Teacher's Training Center, Federal University of Campina Grande. Cajazeiras, Paraíba, Brazil.

$6 \mathrm{PhD}$ in Nursing. Teacher at the Federal University of Paraíba. João Pessoa, Paraíba, Brazil.

Contact information:

Maria do Livramento Silva.

”marialns2010@hotmail.com

\section{Keywords}

Pressure Ulcer; Prevalence; Risk Factors; Nursing

\section{Introduction}

Pressure ulcers may affect hospitalised patients or those under home care, [1] and they are between the third and fourth more expensive health issues in the world and seen as an economic problem for health services. However, implant in the service the patient's risk evaluation 
for developing pressure ulcers, to implement a preventive plan according to the posed risk and carry out actions related to the educational aspects of the health team, client, and family, are strategies that can significantly reduce this problem. [2]

Most pressure ulcers are preventable, and surveys in many countries show that prevention costs are much lower than treatment costs. [3] However, this is a challenge, because in practice there are barriers to solving this problem, such as the lack of a common language among professionals, the lack of material resources to improve preventive practices, and the work overload that healthcare professionals are subjected to, especially nursing staff, making it difficult to perform simple and economic measures, such as repositioning the patient in bed at scheduled times. [4]

Due to their care aspects and complexity, pressure ulcers require multidisciplinary involvement, because their prevention requires specific treatment. However, nursing staff must take more action to address this problem, justified by the own knowledge object and profession work, which is configured to provide continuous care to the patient.

Thus, recognising the impact of pressure ulcers on the patient, the patient's family, professionals, and institutions, this research aimed to determine the prevalence of pressure ulcers and to analyse their association with clinical conditions and the risk factors identified in hospitalised patients in an intensive care unit (ICU).

\section{Method}

This is a prospective and explorative study with a quantitative approach that was conducted in a public hospital ICU in João Pessoa/PB, which has seven beds and receives medical and surgical patients from the hospital or the regulatory system. The studied population consisted of all patients admitted to the ICU from July to October 2012. Forty-five individuals were included in the sample.
Inclusion criteria were as follows: patients aged 18 years or older who stayed in the unit for at least 24 hours, and were subjected to at least two evaluations.

For data collection, we used a form to record the socio-demographic data, the physical examination, and the patient's clinical condition, which were obtained from medical records and through the patient and/or patient's family. We also used the Braden Scale $[5,6]$ to measure the risk of pressure ulcers. Data were analysed using the PASW Statistic Software, version 18. Results were obtained from a descriptive analysis as well as from chi-square association and Fisher's exact tests in their simple and widespread versions.

This research project followed all of the guidelines contained in Resolution $n^{\circ} 466 / 2012$ of the National Health Council [7] and was approved by the Research Ethics Committee of the Health Sciences Centre of the Federal University of Paraíba in Protocol 023/12.

\section{Results}

Regarding the participants' socio-demographic data, the highest occurrences of pressure ulcers were identified in males (11, 24.4\%), Caucasians $(9,20.0 \%)$, and patients over 60 years of age (11, $64.7 \%)$. According to the analysed demographic variables, there was no significant association between patients who developed pressure ulcers and those who did not (Data not presented in table).

Table 1 shows that individuals with pressure ulcers were sedated (20\%), had a satisfactory temperature and peripheral perfusion (33.3\% and 31.1\%, respectively), and were under mechanical ventilation (26.7\%).

Table 2 shows that skin conditions relevant to pressure ulcer development were normal hydration (28.9\%), thin/fine texture (30\%), turgor and decreased elasticity (20\%), and the absence of oedema (24.4\%). 
Table 1. Physical exam findings according to pressure ulcer occurrence. João Pessoa - PB, 2013. $(n=45)$.

\begin{tabular}{|c|c|c|c|c|c|c|c|}
\hline \multirow{3}{*}{$\begin{array}{c}\text { Physical } \\
\text { exam }\end{array}$} & \multicolumn{6}{|c|}{ Pressure ulcers } & \multirow{3}{*}{$\boldsymbol{P}$} \\
\hline & \multicolumn{2}{|c|}{ Yes $(n=17)$} & \multicolumn{2}{|c|}{ No $(n=28)$} & \multicolumn{2}{|c|}{ Total } & \\
\hline & $\mathrm{n}$ & $\%$ & $\mathrm{n}$ & $\%$ & $n$ & $\%$ & \\
\hline \multicolumn{8}{|c|}{ Consciousness level } \\
\hline Lucid & 1 & 2.2 & 18 & 40 & 19 & 42.2 & \multirow{3}{*}{$\begin{array}{c}p^{(1)} \\
<0.001\end{array}$} \\
\hline Sedated* & 9 & 20 & 7 & 15.6 & 16 & 35.6 & \\
\hline Torpor/coma & 7 & 15.6 & 3 & 6.7 & 10 & 22.2 & \\
\hline \multicolumn{8}{|c|}{ Body temperature } \\
\hline Normothermia & 15 & 33.3 & 28 & 62.2 & 43 & 95.5 & \multirow{2}{*}{$\begin{aligned} & p^{(2)} \\
= & 0.137\end{aligned}$} \\
\hline Hyperthermia & 2 & 4.5 & - & - & 2 & 4.5 & \\
\hline \multicolumn{8}{|c|}{ Peripheral perfusion } \\
\hline Normal & 14 & 31.1 & 27 & 60 & 41 & 91.1 & \multirow{2}{*}{$\begin{aligned} & p^{(2)} \\
= & 0.144\end{aligned}$} \\
\hline Reduced & 3 & 6.7 & 1 & 2.2 & 4 & 8.9 & \\
\hline \multicolumn{8}{|l|}{ Ventilation type } \\
\hline Spontaneous & 5 & 11.1 & 15 & 33.3 & 20 & 44.4 & \multirow{2}{*}{$\begin{aligned} & p^{(2)} \\
= & 0.135\end{aligned}$} \\
\hline Mechanical & 12 & 26.7 & 13 & 28.9 & 25 & 55.6 & \\
\hline \multicolumn{8}{|c|}{$\begin{array}{r}\text { Source: Direct research. João Pessoa - PB, } 2013 . \\
\text { *Sedated: using sedative medications, such as midazolan and } \\
\text { dexmedetomidina (precedex). }\end{array}$} \\
\hline \multicolumn{4}{|c|}{$\mathrm{p}^{(1)}$ : Widespread Fisher's exact test. } & \multicolumn{4}{|c|}{$\mathrm{p}^{(2)}$ : Simple Fisher's exact test. } \\
\hline
\end{tabular}

Table 2. Skin conditions according to pressure ulcer occurrence. Joao Pessoa - PB, 2013. ( $n=45)$.

\begin{tabular}{|c|c|c|c|c|c|c|c|}
\hline \multirow{3}{*}{$\begin{array}{c}\text { Physical } \\
\text { exam }\end{array}$} & \multicolumn{6}{|c|}{ Pressure ulcers } & \multirow{3}{*}{$P$} \\
\hline & \multicolumn{2}{|c|}{ Yes $(n=17)$} & \multicolumn{2}{|c|}{ No $(n=28)$} & \multicolumn{2}{|c|}{ Total } & \\
\hline & $n$ & $\%$ & $n$ & $\%$ & $n$ & $\%$ & \\
\hline \multicolumn{8}{|l|}{ Hydration } \\
\hline Normal & 13 & 28.9 & 28 & 62.2 & 41 & 91.1 & \multirow{3}{*}{$\begin{aligned} & p^{(2)} \\
= & 0.016\end{aligned}$} \\
\hline Dry & 2 & 4.4 & - & - & 2 & 4.4 & \\
\hline Peeling & 2 & 4.4 & - & - & 2 & 4.4 & \\
\hline \multicolumn{8}{|l|}{ Texture } \\
\hline Thin/fine & 9 & 30 & 7 & 15.6 & 16 & 35.6 & \multirow{3}{*}{$\begin{aligned} & p^{(2)} \\
= & 0.025\end{aligned}$} \\
\hline Thick & 3 & 6.7 & 2 & 4.4 & 5 & 11.1 & \\
\hline Smooth & 5 & 11.1 & 19 & 42.2 & 24 & 53.3 & \\
\hline \multicolumn{8}{|c|}{ Turgor and elasticity } \\
\hline Normal & 8 & 17.8 & 21 & 46.7 & 29 & 64.4 & \multirow{2}{*}{$\begin{aligned} & p^{(1)} \\
= & 0.107\end{aligned}$} \\
\hline Decreasing & 9 & 20 & 7 & 15.5 & 16 & 35.6 & \\
\hline \multicolumn{8}{|l|}{ Oedema } \\
\hline Yes & 4 & 8.9 & 7 & 15.5 & 11 & 24.4 & \multirow{3}{*}{$\begin{aligned} & p^{(2)} \\
= & 0.896\end{aligned}$} \\
\hline Anasarca & 2 & 4.4 & 2 & 4.4 & 4 & 8.9 & \\
\hline No & 11 & 24.4 & 19 & 42.2 & 30 & 66.7 & \\
\hline
\end{tabular}

Source: Direct research. João Pessoa - PB, 2013 $\mathrm{p}^{(1)}$ : Widespread Fisher's exact test. $\quad \mathrm{p}^{(2)}$ : Simple Fisher's exact test.

Table 3. Braden Scale scores in patients with and without pressure ulcers. Joao Pessoa - PB, 2013. $(n=45)$.

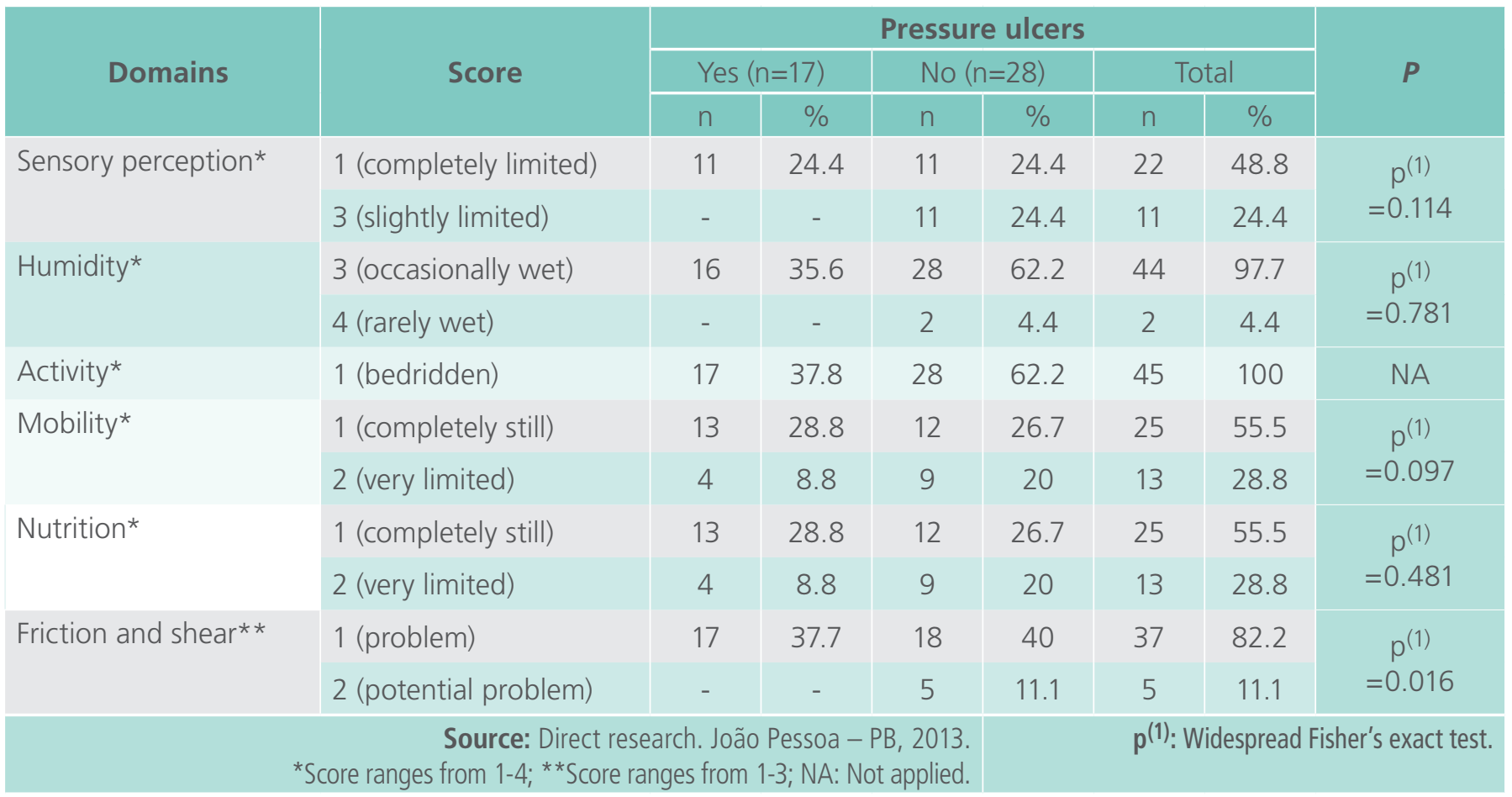


Table 3 presents the data from the Braden Scale scores, $[5,6]$ in which pressure ulcer prevalence was observed in the sensory perception domains: completely limited (24.4\%); humidity: occasionally wet (35.6\%); activity: bedridden (37.8\%); mobility: completely still (28.8\%); nutrition: suitable (20\%); and friction and shear: problem (37.7\%).

By that scale $d$ that most patients had scores worst condition scores, classified as high risk (30, $66.7 \%$ ). It was observed that in the subscale friction and shear, from those that had been classified with problem in this item, 17 (37.7\%) presented the lesion, what is the worst clinical status and thus, high risk for developing pressure ulcers, was also observed a significant association between this area and the lesion occurrence $(p=0.016)$.

\section{Discussion}

Pressure ulcers are the most frequent complications in the ICU as a result of invasive procedures and a greater need for handling. The patients in this unit are in serious condition, have associated morbidities, are bedridden, and have limited movement; therefore, they are more prone to forming lesions. [8, 9]

In this research, from the 45 patients in the sample, 9 were admitted with previous pressure ulcers, and 8 developed pressure ulcers after the hospitalisation, representing a prevalence of $37.8 \%$. Similarly, a study conducted in an ICU [10] identified index at the same level. However, even higher rates were found for the same scenario, showing that the numbers can fluctuate depending on the researched institutional reality and the methodology used. $[5,11]$

Thus, the findings confirm that pressure ulcers still have an impact on patient care in Brazilian ICUs, even with all the material resources available to prevent these lesions and updates available for professionals.
Regarding the socio-demographic data from pressure ulcer patients, deserve to be highlighted, also, the pilot prospective study results performed in a university hospital ICU in southern Brazil, in which was found a predominance of males and Caucasians in the group that developed pressure ulcers [12]; and a sectional survey that approached 22 ICUs in 15 public and private hospitals in Belo Horizonte/MG, in which was found $53 \%$ of males and $65 \%$ of Caucasians. However, there was no significant statistical difference between these variables. [10]

Regarding age, the highest occurrence of pressure ulcers was in seniors older than 60 years of age; this finding is similar to other studies, $[5,13]$ although a significant association has not been found in this variable. However, it is noteworthy that the risk of pressure ulcers increases in the elderly due to skin characteristics and subcutaneous tissue changes, a senescence result. $[14,15]$

The evaluation of consciousness level showed that most patients with pressure ulcers were sedated or in a state of torpor/coma, showing an association between variables $(p<0.001)$. This confirms the greater susceptibility to developing pressure ulcers in sedated patients, [14] because changes in consciousness are related to sensory perception, mobility, and activity, which, in an isolated or associated form, may initiate the formation of pressure ulcers. [6]

When a patient presents a change in sensory perception, there is a need for increased attention, given the patient's inability to express discomfort, which makes him or her more susceptible to forming a pressure ulcer. [16] Thus, the importance of gradually undoing the sedation and using all available resources to prevent these injuries is reinforced.

In relation to body temperature, peripheral perfusion, and ventilation type, although a significant association between these variables and pressure 
ulcer occurrence was not observed, this problem is not found in patients with adequate temperature and perfusion and under spontaneous ventilation.

A study conducted in the intensive and semiintensive care units in Rio Grande do Sul hospitals found a significance between the amount of time under mechanical ventilation and pressure ulcer development. [17] Another study showed that the use of mechanical ventilation is an additional risk for pressure ulcers $(p=0.001)$. [18]

Therefore, the use of mechanical ventilation in addition to represent the patient difficulty to keep a ventilation-perfusion adequate relationship, can compromise the handling of the patient in bed, causing greater immobility and exposure of bony prominences to ongoing pressures.

The association between pressure ulcers and friction and shear found in this study corroborates findings from a study conducted in 22 ICUs in Belo Horizonte/MG, [19] which found that in the problem item more ulcers were identified in patients categorised in the domain friction and shear.

Comparing the findings, although pressure ulcers are greater in patients with a low consciousness level and low skin texture, as well as friction and shear, we cannot say that these are isolated factors that contribute to lesion development. Therefore, a more appropriate epidemiological study is necessary, such as a case-control study.

Furthermore, it is worth emphasising that measures to prevent pressure ulcers do not require complex resources or new technologies; rather, they require only professionals' knowledge about the multiple causes of pressure ulcers and their commitment to the patient and the health service. Simple measures with low cost may represent an advantage for nursing care, reflecting better results in the prevention of pressure ulcers and other preventable injuries.

\section{Conclusion}

The results of this study reaffirm the need for the health team and, particularly, nursing professionals to be involved in preventive care through simple measures for the maintenance of skin health.

\section{References}

1. Rolim JA, Vasconcelos JMB, Caliri MHL, Santos IBC. Prevenção e tratamento de úlceras por pressão no cotidiano de enfermeiros intensivistas. Rev Rene [Internet], 2013; 14(1): 148-57. Available from: http://www.revistarene.ufc.br/revista/index. php/revista/article/view/336

2. National Pressure Ulcer Advsory Panel. Pressure Ulcer Stages Revised by NPUAP. Washington (DC): NPUAP; 2009.

3. Rodrigues MM, Souza MS, Silva JL. Sistematização da assistência de enfermagem na prevenção da lesão tecidual por pressão. Cogitare Enferm [Internet], 2008 Out/Dez; 13(4): 566-75. Available from: http://ojs.c3sl.ufpr.br/ojs2/index.php/cogitare/ article/view/13117/8875

4. Irion G. Feridas. Novas abordagens, manejo clínico e Atlas em cores. 2 ed. Rio de Janeiro: Guanabara Koogan, 2012.

5. Rogenski NMB, Kurcgant P. Avaliação da concordância na aplicação da Escala de Braden Interobservadores. Acta Paul Enferm [Internet], São Paulo, 2012; 25(1): 24-8. Available from: http://www.redalyc.org/articulo.oa?id=307023882005

6. Braden B, Bergstrom N. A conceptual schema for the study of the etiology of pressure sore. Rehab Nurs. 1987; 12(1): 8-12. PMID: 3643620

7. Ministério da saúde (BR). Conselho Nacional de Saúde. Comissão Nacional de Ética em Pesquisa. Normas regulamentadoras de pesquisa envolvendo seres humanos: Resolução 466/12. Brasília (DF): Ministério da Saúde; 2012.

8. Fernandes NCS, Torres GV. Incidência e fatores de risco de úlceras de pressão em pacientes de unidade de terapia intensiva. Cienc Cuid Saude [Internet], 2008 Jul/Set; 7(3): 304-310. Available from: https://sigaa.ufrn.br/sigaa/verProducao?idProducao=1343 584\&key=a260480cbbd172aabbc37ce610831fda

9. Cremasco MF, Wenzel F, Sardinha FM, Zanei SSV, Whitaker IY. Úlcera por pressão: risco e gravidade do paciente e carga de trabalho de enfermagem. Acta Paul Enferm [Internet], 2009; 22(n. esp.): 897-902. DOI: http://dx.doi.org/10.1590/s0103$\underline{21002009000700011}$ 
10. Gomes FSL, Bastos MAR, Matozinhos FP, Temponi HR, Velásquez-Meléndez G. Factors associated to pressure ulcers in patients at Adult Intensive Care Units. Rev EsC Enferm USP [Internet], São Paulo, 2010; 44(4): 1065-71. DOI: http://dx.doi. org/10.1590/S0080-62342010000400031

11. Matos LS, Duarte NLV, Minetto RC. Incidência e prevalência de úlcera por pressão no CTI de um Hospital Público do DF. Rev Eletr Enf [Internet], 2010; 12(4): 19-26. DOI: 10.5216/ree. v12i4.8481

12. Bavaresco T, Medeiros RH, Lucena AF. Implantação da escala de Braden em uma unidade de terapia intensiva de um hospital universitário. Rev Gaúcha Enferm [Internet], Porto Alegre, 2010; 32(4): 703-10. DOI: http://dx.doi.org/10.1590/S198314472011000400010

13. Soares DAS, Vendramin FS, Pereira LMD, Proença PK, Marques MM. Análise da incidência de úlcera de pressão no hospital metropolitano de urgência e emergência em Ananindeua, PA. Rev Bras Cir Plást [Internet], São Paulo, 2011 Nov/Dec; 26(4): 578-

81. DOI: http://dx.doi.org/10.1590/S1983-51752011000400007

14. Sayar S, Turgut S, Dogan H, Ekici A, Yurtsever S, Demirkan F et al. Incidence of pressure ulcers in intensive care unit patients at risk according to the Waterlow scale and factors influencing the development of pressure ulcers. J Clin Nurs [Internet], 2009; 18(5): 765-74. DOI: 10.1111/j.1365-2702.2008.02598.x.

15. Fernandes MGM, Costa KNFM, Santos SR, Pereira MA, Oliveira DST, Brito SS. Risco para úlceras por pressão em idosos hospitalizados: aplicação da escala de Waterlow. Rev enferm UERJ [Internet], 2012; 20(1): 56-60. Available from: http://www.e-publicacoes.uerj.br/index.php/enfermagemuerj/ article/view/3977/2759

16. Silva EWNL, Araújo RA, Oliveira EC, Falcão VTFL. Aplicabilidade do protocolo de prevenção de úlcera de pressão em unidade de terapia intensiva. Rev Bras Ter Intensiva [Internet], São Paulo, 2010 Apr/Jun; 22(2): 175-85. DOI: http://dx.doi.org/10.1590/ $\underline{\text { S0103-507X2010000200012 }}$
17. Rockenbach CWF, Borges AM, Amaral RB, Bordin E. Fatores de risco para desenvolvimento de úlceras de pressão em UTI. Con Scientiae Saúde [Internet], São Paulo, 2012; 11(2): 249-55. Available from: http://www.redalyc.org/articulo. oa?id=92923674007

18. Hans M, Bitencourt JVOV, Pinheiro F. Fatores de risco adicionais à escala de Braden: um risco para úlceras de pressão. Enfermagem em Foco [Internet], 2011; 2(4): 222-5. Available from: http://revista.portalcofen.gov.br/index.php/enfermagem/ article/view/188

19. Gomes FSL, Bastos MAR, Matozinhos FP, Temponi HR, Velásquez-Meléndez G. Avaliação de risco para úlcera por pressão em pacientes críticos. Rev Esc Enferm USP [Internet], São Paulo, 2011 Apr; 45(2): 313-18. DOI: http://dx.doi.org/10.1590/ $\underline{\text { S0080-62342011000200002 }}$
Publish in International Archives of Medicine

International Archives of Medicine is an open access journal publishing articles encompassing all aspects of medical science and clinical practice. IAM is considered a megajournal with independent sections on all areas of medicine. IAM is a really international journal with authors and board members from all around the world. The journal is widely indexed and classified Q1 in category Medicine. 